\title{
Neuropsychiatric Disorders in Cushing's Syndrome
}

\author{
Alberto M. Pereira Jitske Tiemensma Johannes A. Romijn \\ Department of Endocrinology and Metabolic Diseases, Leiden University Medical Center, Leiden, The Netherlands
}

\section{Key Words}

Cushing's syndrome $\cdot$ Treatment $\cdot$ Depression $\cdot$ Mania $\cdot$

Psychopathology

\begin{abstract}
Glucocorticoids are crucial in the initiation and consolidation of the stress response. Patients with active Cushing's syndrome (CS) are exposed to excessive endogenous glucocorticoid levels. In these patients, psychopathology is often being observed. The most common co-morbid disorder is major depression, but to a lesser extent mania and anxiety disorders have also been reported. A severe clinical presentation of CS often also includes depression. Reduction of glucocorticoid synthesis or action, either with metyrapone, ketoconazole, or mifepristone, rather than treatment with antidepressant drugs, is generally successful in relieving depressive symptoms, as well as other disabling symptoms. Following successful surgical treatment of hypercortisolism, both physical and psychiatric signs and symptoms improve substantially. However, it appears that patients do not completely return to their premorbid level of functioning and persistent impairment of quality of life and cognitive function has been reported despite long-term cure. At present, it is not clear whether, and to which extent, psychopathology still affects general well-being after long-term cure of CS.
\end{abstract}

Copyright $\odot 2010$ S. Karger AG, Basel

\section{Introduction}

Cushing's syndrome (CS) is associated with psychopathology. The spectrum of behavioral abnormalities observed in patients with CS ranges from severe depression to mania and can be present in both endogenous CS and in patients exposed to exogenous corticosteroids, which strongly suggests a causal role for corticosteroid excess in the initiation and consolidation of psychopathology. In this concise review, we will address the pathophysiology of the neuropsychiatric disorders observed in CS. In order to emphasize the crucial role of corticosteroid excess in the control of mood and behavior and cognitive function, we will first discuss the data on psychopathology observed in active CS, then the effects of reduction of corticosteroid synthesis or action on psychopathology in CS, and, finally, the reversibility of psychopathology after remission of glucocorticoid excess.

\section{Physiology and Pathophysiology of the Control of Behavior in Response to Stress}

In order to put the behavioral abnormalities observed in CS into the right perspective, it is important to realize that cortisol (or corticosterone in the rodent) is the main mediator of the stress response [1]. When an individual is

\section{KARGER}

Fax +4161306 1234 E-Mail karger@karger.ch www.karger.com
Alberto M. Pereira

Department of Endocrinology and Metabolism

Leiden University Medical Center

NL-2333 ZA Leiden (The Netherlands)

Tel. +31 71526 3738, Fax +31 71524 6017, E-Mail a.m.pereira@lumc.nl 
exposed to a stressor, rapid changes occur within seconds to minutes through stimulation of the sympathetic nervous system via catecholamines (CRH, AVP) and via nongenomic actions of cortisol. These mediators increase excitability, resulting in behavioral changes characterized by increased vigilance, alertness, arousal, and attention. In addition, the stress response is characterized by slower changes that occur within minutes to hours via stimulation of both the mineralocorticoid (MR) and glucocorticoid (GR) receptor. All these changes, in the end, occur only with the purpose to induce the required behavioral adaptations for the individual to be able to adequately cope with the stressor. However, when the stressor becomes chronic, a so-called vulnerable phenotype develops, characterized by neurodegenerative changes within the central nervous system and cognitive impairment [1]. Thus, it is not surprising that CS, that can be considered the clinical human equivalent for severe chronic stress, is associated with behavioral abnormalities.

\section{Psychopathology in Active Cushing's Syndrome}

Active, untreated CS is associated with a high prevalence of psychopathology. The frequencies of psychiatric symptoms have been evaluated since the late 1970s using different criteria in a total of approximately 500 patients with CS, mostly comprising small patient groups. A subset of these studies that evaluated psychopathology and personality traits are summarized in table 1. An early study on personality traits in 53 patients with CS reported that $60 \%$ of these subjects had personality changes [2]. However, it is not clear from the data in that study whether these patients still had active Cushing's disease. Another study in 9 patients with active Cushing's disease concluded that patients had a higher tendency for anxiety than controls [3]. In contrast, Kelly et al. [4] concluded that patients with active CS and control patients scored equally on personality traits (neuroticism and extraversion). Starkman and Schteingart [5] evaluated the prevalence of psychiatric symptoms in 35 patients with active CS and found that irritability, depressed mood, and anxiety were present in the majority of the patients. Intriguingly, an increased overall psychiatric disability, measured by and indicated by a specific score, was associated with increased cortisol secretion. Among another consecutive unselected series of 29 patients with untreated CS, 25 (86\%) were significantly depressed. In this study, the severity of the depression was not related to circulat- ing cortisol levels, but the depression was rapidly relieved when the tumor or adrenal glands were removed [6]. Kelly et al. [7] compared in another study 15 patients with active CS both with 15 other patients who had been treated successfully for CS and with 13 patients with other pituitary tumors. Depression was the main psychiatric diagnosis using the CATEGO program after Present State Examinations. Patients with active CS were significantly more depressed (Hamilton Rating Scores) than were the other patients. Another study [8] compared 20 patients with Cushing's disease with 20 patients with major depressive disorder using the Structured Clinical Interview for DSM-III-R (SCID) and Research Diagnostic Criteria. A diagnosis of generalized anxiety disorder, major depressive disorder, or panic disorder, either alone or in combination, was present in approximately two thirds of the patients with Cushing's disease. Interestingly, behavioral symptoms usually first occurred at or after the onset of the first physical symptoms. However, the onset of panic disorder was associated with more chronic stages of active Cushing's disease. In agreement with the studies that involved small patient numbers, psychopathology was highly prevalent in a large cohort of $162 \mathrm{pa}-$ tients with Cushing's disease reported by Sonino et al. [9]. Major depression, according to DSM-IV criteria, was present in more than $50 \%$ of the patients. Interestingly, the presence of psychopathology was significantly associated with older age, female gender, higher pretreatment 24-hour urinary cortisol levels, a more severe clinical condition, and absence of pituitary adenoma (table 2). This has led to the inclusion of mood disorders in a clinical index for rating the severity of CS [10].

\section{Effects of Reduction of Corticosteroid Synthesis or Action on Psychopathology in Cushing's Syndrome}

Only a few studies with a limited number of patients have reported the effects of successful reduction of corticosteroid excess on psychopathology. These studies demonstrate that both reduction of corticosteroid synthesis with ketoconazole or metyrapone and blockade of the glucocorticoid receptor with mifepristone positively affect psychopathology. The first study that reported the effects of medical treatment of patients with CS was published in 1979 [11]. In this study, in 38 patients with CS, $65 \%$ were diagnosed with depression of different clinical severity. The majority of the patients were treated with metyrapone which resulted in remission of psychiatric symptoms in virtually all of them [11]. This impressive 
Table 1. Overview of studies on psychopathology and personality traits in patients with Cushing's disease and Cushing's syndrome

\begin{tabular}{|c|c|c|c|c|c|c|}
\hline $\begin{array}{l}\text { Author, } \\
\text { year }\end{array}$ & $\begin{array}{l}\text { Number of } \\
\text { subjects }\end{array}$ & $\begin{array}{l}\text { Gender } \\
(\mathrm{M} / \mathrm{F})\end{array}$ & $\begin{array}{l}\text { Age } \\
\text { years (SD) }\end{array}$ & Active/treated & Methods & Outcomes \\
\hline $\begin{array}{l}\text { Starr, } \\
1951[2]\end{array}$ & $\begin{array}{l}53 \text { Cushing's } \\
\text { syndrome }\end{array}$ & NA & NA & NA & NA & $\begin{array}{l}\text { Of all patients, } 35 \% \text { had marked } \\
\text { personality alterations, and } 25 \% \text { showed } \\
\text { frank psychosis which resulted in } \\
\text { institutionalization. }\end{array}$ \\
\hline
\end{tabular}

\begin{tabular}{ll}
\hline Cohen, & 29 Cushing's \\
$1980[6]$ & syndrome
\end{tabular}

Almost all were seen
during admission for
diagnosis. A few
were first seen
immediately after
surgery

\begin{tabular}{|c|c|c|c|c|c|}
\hline $\begin{array}{l}\text { Sablowski } \\
\text { et al., } \\
1986[3]\end{array}$ & $\begin{array}{l}9 \text { Cushing's } \\
\text { disease } \\
9 \text { acromegaly }\end{array}$ & $\begin{array}{l}\text { Not } \\
\text { given }\end{array}$ & $\mathrm{NA}$ & $\begin{array}{l}\text { Before and after } \\
\text { surgery }\end{array}$ & $\begin{array}{l}\text { Freiburger Personality } \\
\text { Inventory, Giessen test, State- } \\
\text { Trait-Anxiety Inventory }\end{array}$ \\
\hline
\end{tabular}

6 prolactinoma

24 controls

\section{Interviews.}

Detailed clinical history and

an examination of mental state

Of all patients, $86 \%$ had distinct affective disorders. Twenty-five patients suffered from depression, and one had manic and depressive episodes.

\begin{tabular}{|c|c|c|c|c|c|}
\hline $\begin{array}{l}\text { Kelly et al., } \\
1996 \text { [4] }\end{array}$ & $\begin{array}{l}43 \text { Cushing's } \\
\text { syndrome } \\
24 \text { acromegaly } \\
\text { and } \\
\text { prolactinoma }\end{array}$ & $10 / 33$ & NA & $\begin{array}{l}\text { Prospective study. } \\
\text { Before and after } \\
\text { treatment }\end{array}$ & $\begin{array}{l}\text { Present state examination, } \\
\text { Hamilton rating scale Crown- } \\
\text { Crisp experiential index, } \\
\text { Eysenck personality inventory }\end{array}$ \\
\hline
\end{tabular}

\begin{abstract}
Pre-operatively, there is a tendency to higher scores of trait-anxiety in pituitary patients compared to controls.

This did not change after surgery.

Furthermore, Cushing's disease patients seemed more nervous and restrained than acromegaly patients.
\end{abstract}

Present state examination: only $19 \%$ of the active Cushing's syndrome patients were normal, whereas $87 \%$ of the controls were normal.

Depression and all scales of the CrownCrisp improved after treatment. When patients were re-assessed after appropriate treatment, there was a significant decrease in neuroticism score but no change in extraversion

\begin{tabular}{|c|c|c|c|c|c|}
\hline $\begin{array}{l}\text { Dorn et al., } \\
1995[20]\end{array}$ & $\begin{array}{l}33 \text { Cushing's } \\
\text { syndrome } \\
17 \text { matched } \\
\text { hospitalized } \\
\text { controls }\end{array}$ & $5 / 28$ & $36 \pm 9$ & $\begin{array}{l}\text { Hypercortisolemic } \\
\text { during interview }\end{array}$ & $\begin{array}{l}\text { Interviews, atypical depression } \\
\text { diagnostic scale, Hamilton } \\
\text { rating scale, self-report } \\
\text { instruments, medical records } \\
\text { information }\end{array}$ \\
\hline
\end{tabular}

\begin{tabular}{lllll}
\hline $\begin{array}{l}\text { Dorn et al., } 33 \text { Cushing's } \\
1997 \text { [15] }\end{array}$ syndrome & $5 / 28$ & $36 \pm 9$ & $\begin{array}{l}\text { Before and 3, } 6 \text { and } \\
12 \text { months after } \\
\text { correction for } \\
\text { hypercortisolism }\end{array}$ & $\begin{array}{l}\text { Interviews, atypical depression } \\
\text { diagnostic scale, Hamilton } \\
\text { rating scale, self-report } \\
\text { instruments, medical records } \\
\text { information }\end{array}$
\end{tabular}

information

Anytime during the active phase, $67 \%$ of the patients had at least one diagnosis. Atypical depression was the most frequent finding $(52 \%)$. The duration of CS was an important factor in predicting whether patients sought psychological intervention.

Before cure, $67 \%$ had significant psychopathology. After cure, overall psychopathology decreased to $54 \%$ at 3 months, $36 \%$ at 6 months, and $24 \%$ at 12 months. There was an inverse correlation between psychological recovery and baseline morning cortisol. Atypical depression remained the most frequent finding.

\begin{tabular}{|c|c|c|c|c|c|c|}
\hline $\begin{array}{l}\text { Flitsch et } \\
\text { al., } \\
2000[21]\end{array}$ & $\begin{array}{l}19 \text { Cushing's } \\
\text { disease } \\
18 \text { acromegaly } \\
11 \text { NFMA }\end{array}$ & $7 / 12$ & $34 \pm 12$ & $\begin{array}{l}\text { Before and after (6 } \\
\text { months) } \\
\text { transsphenoidal } \\
\text { microsurgery }\end{array}$ & $\begin{array}{l}\text { Semi-structured interview, } \\
\text { Freiburger Persönlichkeits- } \\
\text { inventar, State-trait-anxiety- } \\
\text { inventory, Rosenzweig picture } \\
\text { frustration test, } \\
\text { Befindlichkeitsskala, Giessener } \\
\text { Beschwerdebogen }\end{array}$ & $\begin{array}{l}\text { Most common psychopathological signs } \\
\text { were excitability and depression. At least } \\
\text { one of these signs was found in } 12 \text { out of } \\
19 \text { Cushing's disease patients. } \\
6-8 \text { months after surgery, the majority of } \\
\text { the Cushing's disease patients (10 of 19) } \\
\text { noticed an increase in physical well-being. }\end{array}$ \\
\hline $\begin{array}{l}\text { Sonino, } \\
2006 \text { [19] }\end{array}$ & $\begin{array}{l}24 \text { Cushing's } \\
\text { syndrome } \\
24 \text { healthy } \\
\text { matched } \\
\text { controls }\end{array}$ & $5 / 19$ & $35 \pm 11$ & $\begin{array}{l}1-3 \text { years in } \\
\text { remission }\end{array}$ & $\begin{array}{l}\text { Tridimensional personality } \\
\text { questionnaire, Symptom } \\
\text { Rating Test }\end{array}$ & $\begin{array}{l}\text { No significant differences in personality } \\
\text { dimensions between patients and } \\
\text { controls. On the Symptom Rating Test, } \\
\text { patients scored higher on anxiety, } \\
\text { depression and psychotic symptoms } \\
\text { compared to controls. }\end{array}$ \\
\hline
\end{tabular}


Table 2. Demographic and clinical correlates of major depression in pituitary-dependent Cushing's disease (reproduced with permission from Sonino et al. [9] and S. Karger AG, Basel)

\begin{tabular}{|c|c|c|c|}
\hline & $\begin{array}{l}\text { Nondepressed } \\
\text { patients }(\mathrm{n}=74)\end{array}$ & $\begin{array}{l}\text { Depressed } \\
\text { patients }(n=88)\end{array}$ & $\begin{array}{l}\mathrm{p} \\
\text { value }\end{array}$ \\
\hline Mean age $( \pm S D)$, years & $34.5 \pm 13.5$ & $40.0 \pm 11.4$ & $<0.01$ \\
\hline Sex, male/female & $26 / 48$ & $12 / 76$ & $<0.01$ \\
\hline Urinary cortisol, nmol/day & $1,076 \pm 786$ & $1,694 \pm 1,170$ & $<0.001$ \\
\hline Plasma ACTH, pmol/l & $15.9 \pm 9.4$ & $18.8 \pm 12.2$ & NS \\
\hline \multirow{2}{*}{$\begin{array}{l}\text { Clinical presentation, } \\
\text { mild/severe } \\
\text { Pituitary lesion }{ }^{2} \text {, adenoma/ } \\
\text { no adenoma }\end{array}$} & $62 / 12$ & $12 / 76$ & $<0.001$ \\
\hline & $45 / 8$ & $41 / 21$ & $<0.05$ \\
\hline $\begin{array}{l}\mathrm{NS}=\text { Not significant. } \\
{ }^{1} \mathrm{By} \chi^{2} \text { or } \mathrm{t} \text { test. }{ }^{2} \text { Data a }\end{array}$ & 115 cases. & & \\
\hline
\end{tabular}

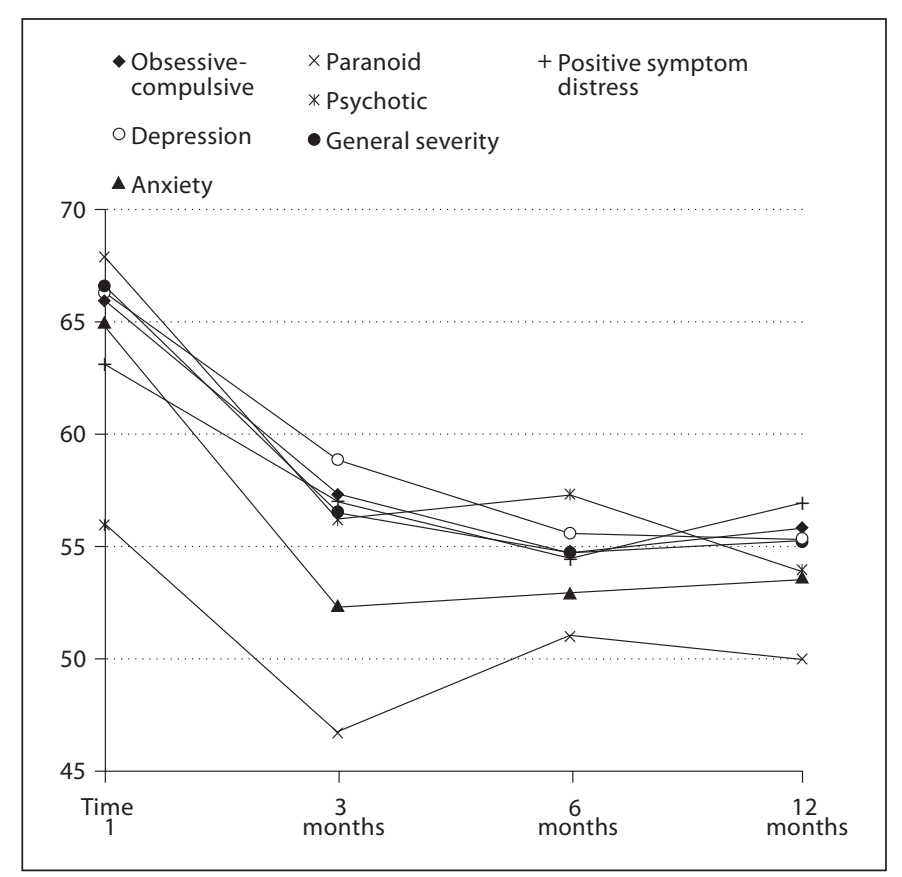

Fig. 1. Significant changes in mean $\mathrm{T}$ scores of subscales of the Symptom Checklist-90R for patients with CS during CS (time 1) and 3, 6, and 12 months after treatment. From Dorn et al. [15]; copyright 1997, The Endocrine Society, with permission.

treatment efficacy was later confirmed in another study with 53 patients with Cushing's disease pretreated with metyrapone and 24 patients who had been given pituitary irradiation for a median duration of 27 months [12]. In contrast to metyrapone, a total of only 20 patients with CS have been reported that were treated with the GR antagonist mifepristone. The clinical applicability and ef- fectivity of mifepristone in these CS patients was reviewed recently [13]. Treatment with mifepristone resulted in a dramatic improvement of clinical signs in 15/20 patients. In parallel, in 3 of the 4 patients with psychopathology a significant improvement was reported. It is important to note that the beneficial effects of mifepristone on psychopathology already occur within a few days after the initiation of treatment.

\section{Reversibility of Psychopathology after Remission of Cushing's Syndrome}

The literature is even scarcer when the potential reversibility of psychopathology after successful surgical treatment of CS is considered. The paucity of data after treatment indicates that a significant improvement occurs within the first year after treatment. Starkman et al. [14] reported significant improvement in both the depressed mood score and the modified Hamilton depression score in 23 patients with pituitary-dependent CS after treatment, which were also significantly correlated to decreases in urinary cortisol excretion. The longitudinal course of psychopathology in CS after correction of hypercortisolism was evaluated in 33 patients with active CS before and 3, 6 and 12 months after successful surgery. Before cure, $67 \%$ of the patients had significant psychopathology, predominantly atypical depressive disorder and/or major affective disorder. After cure, overall psychopathology decreased significantly to $54 \%$ at 3 months, $36 \%$ at 6 months, and $24 \%$ at 12 months, when there was a parallel recovery of the hypothalamic-pituitary-adrenal axis (fig. 1). The authors also found an inverse correlation between psychological recovery and baseline morning 
cortisol. Intriguingly, even after correction of hypercortisolism, atypical depressive disorder continued to be the prevailing diagnosis, whereas the frequency of suicidal ideation and panic disorder increased [15]. In our Leiden series of patients treated for Cushing's disease, we have documented persistent psychopathology in CS even after long-term remission for a mean of 13 years using general health-related questionnaires, like the Hospital Anxiety and Depression Scale (HADS) and the Nottingham Health Profile (NHP) [16]. Noteworthy, some but not all items were no longer significant when corrected for hypopituitarism, indicating that hypopituitarism per se also importantly influences psychological well-being. The general clinical impression, however, is that the final outcomes of treatment of CS are far from satisfactory [17]. In agreement, we recently documented in our Leiden cohort of 74 patients treated for Cushing's disease that cognitive function, reflecting memory and executive functions, was persistently impaired despite long-term cure. Compared with patients that had been treated for nonfunctioning pituitary macroadenomas (NFMA), patients cured from Cushing's disease had lower scores on the Mini Mental State Examination, and on the memory quotient of the Wechsler Memory Scale. Furthermore, patients cured from Cushing's disease tended to recall fewer words on the imprinting, immediate recall, and delayed recall trials of the Verbal Learning Test of Rey. Patients cured from Cushing's disease also had lower scores on the Rey Complex Figure Test on both trials compared with NFMA patients. Finally, patients cured of Cushing's disease also made fewer correct substitutions (on the Letter-Digit Substitution Test) and came up with fewer correct patterns (on the Figure Fluency Test) compared with treated NFMA patients [18]. These observations indicate irreversible effects of previous hypercortisolism on cognitive function and, thus, on the central nervous system.
Furthermore, in some, but not all, studies [2, 4, 19-21] maladaptive personality traits were documented after treatment for Cushing's disease. When patients with CS were re-assessed after appropriate treatment, there was a significant decrease in neuroticism score but no change in extraversion [4]. However, another recent study concluded that there were no differences in personality traits between patients with CS in remission and controls [19]. Therefore, maladaptive personality traits are documented after treatment of Cushing's disease in some, but not all, studies. However, definite conclusions on the extent of normalisation of mood and behavior cannot be drawn from these studies because they included only limited numbers of patients with heterogeneous clinical characteristics. Moreover, the long-term effects of cured Cushing's disease have not been studied in detail.

\section{Conclusion}

Active CS is associated with a high prevalence of psychopathology, mainly atypical depression. Treatments with glucocorticoid reducing or blocking agents can rapidly relief symptoms. After successful surgery, psychopathology decreases but mood and behavior do not seem to normalize. After long-term remission, patients with Cushing's disease still show decreased quality of life and impaired cognitive function. Future studies should aim at further investigating if and how CS longitudinal changes affect (subclinical) psychopathology.

\section{Disclosure Statement}

The authors have nothing to declare.

\section{References}

1 de Kloet ER, Joëls M, Holsboer F: Stress and the brain: from adaptation to disease. Nat Rev Neurosci 2005;6:463-475.

2 Starr AM: Personality changes in Cushing's syndrome. J Clin Endocrinol Metab 1952;12: 502-505.

-3 Sablowski N, Pawlik K, Ludecke DK, Herrmann HD: Aspects of personality in patients with pituitary adenomas. Acta Neurochir (Wien) 1986;83:8-11.
-4 Kelly WF, Kelly MJ, Faragher B: A prospective study of psychiatric and psychological aspects of Cushing's syndrome. Clin Endocrinol (Oxf) 1996;45:715-720.

5 Starkman MN, Schteingart DE: Neuropsychiatric manifestations of patients with Cushing's syndrome: relationship to cortisol and adrenocorticotropic hormone levels. Arch Intern Med 1981;141:215-219.

6 Cohen SI: Cushing's syndrome: a psychiatric study of 29 patients. Br J Psychiatry 1980; 136:120-124.
Kelly WF, Checkley SA, Bender DA: Cushing's syndrome, tryptophan and depression. Br J Psychiatry 1980;136:125-132.

$\checkmark 8$ Loosen PT, Chambliss B, DeBold CR, Shelton R, Orth DN: Psychiatric phenomenology in Cushing's disease. Pharmacopsychiatry 1992;25:192-198.

-9 Sonino N, Fava GA, Raffi AR, Boscaro M, Fallo F: Clinical correlates of major depression in Cushing's disease. Psychopathology 1998;31:302-306. 
-10 Sonino N, Boscaro M, Fallo F, Fava GA: A clinical index for rating severity in Cushing's syndrome. Psychother Psychosom 2000;69: 216-220.

-11 Jeffcoate WJ, Silverstone JT, Edwards CR, Besser GM: Psychiatric manifestations of Cushing's syndrome: response to lowering of plasma cortisol. Q J Med 1979;48:465-472.

$\checkmark 12$ Verhelst JA, Trainer PJ, Howlett TA, Perry L, Rees LH, Grossman AB, Wass JA, Besser GM: Short and long-term responses to metyrapone in the medical management of 91 patients with Cushing's syndrome. Clin Endocrinol (Oxf) 1991;35:169-178.

13 Castinetti F, Fassnacht M, Johanssen S, Terzolo M, Bouchard P, Chanson P, Do Cao C, Morange I, Picó A, Ouzounian S, Young J, Hahner S, Brue T, Allolio B, Conte-Devolx B: Merits and pitfalls of mifepristone in Cushing's syndrome. Eur J Endocrinol 2009;160: 1003-1010.
14 Starkman MN, Schteingart DE, Schork MA: Cushing's syndrome after treatment: changes in cortisol and ACTH levels, and amelioration of the depressive syndrome. Psychiatry Res 1986;19:177-188.

15 Dorn LD, Burgess ES, Friedman TC, Dubbert B, Gold PW, Chrousos GP: The longitudinal course of psychopathology in Cushing's syndrome after correction of hypercortisolism. J Clin Endocrinol Metab 1997; 82:912-919.

16 van Aken MO, Pereira AM, Biermasz NR van Thiel SW, Hoftijzer HC, Smit JW, Roelfsema F, Lamberts SW, Romijn JA: Quality of life in patients after long-term biochemical cure of Cushing's disease. J Clin Endocrinol Metab 2005;90:3279-3286.

17 Sonino N, Fallo F, Fava G: Psychosomatic aspects of Cushing's syndrome. Rev Endocr Metab Disord 2009; in press. DOI 10.1007/ s11154-009-9123-7.
18 Tiemensma J, Kokshoorn NE, Biermasz NR, Keijser BJ, Wassenaar MJ, Middelkoop HA, Pereira AM, Romijn JA: Subtle cognitive impairments in patients with long-term cure of Cushing's disease. J Clin Endocrinol Metab 2010;95:2699-2714.

19 Sonino N, Bonnini S, Fallo F, Boscaro M, Fava GA: Personality characteristics and quality of life in patients treated for Cushing's syndrome. Clin Endocrinol (Oxf) 2006; 64:314-318.

20 Dorn LD, Burgess ES, Dubbert B, et al: Psychopathology in patients with endogenous Cushing's syndrome: 'atypical' or melancholic features. Clin Endocrinol (Oxf) 1995; 43:433-442.

$>21$ Flitsch J, Spitzner S, Ludecke DK: Emotional disorders in patients with different types of pituitary adenomas and factors affecting the diagnostic process. Exp Clin Endocrinol Diabetes 2000;108:480-485. 